\title{
PENGARUH MEDIA PENDINGIN AIR PADA KONDENSOR TERHADAP KEMAMPUAN KERJA MESIN PENDINGIN
}

\author{
Kemas. Ridhuan ${ }^{1)}$, I Gede Angga J. ${ }^{2)}$ \\ Jurusan Teknik Mesin Fakultas Teknik Universitas Muhammadiyah Metro ${ }^{1,2)}$ \\ Jl. Ki Hjar Dewantara No. 116 Kota Metro \\ kmsridhuan@yahoo.co.id
}

\begin{abstract}
Abstrak
Kondensor berfungsi untuk membuang panas yang ada pada refrigran, sehingga freon dapat diproses pada evaporator untuk menyerap panas kembali. Untuk meningkatkan proses pembuangan panas di kondensor perlu dilakukan penyerapan panas pada refrigran yang lebih optimal seperti penggunaan air sebagai media pendingin. Tujuan dari penelitian ini adalah untuk mengetahui pengaruh media pendingin air terhadaop kemampuan kerja COP (Coefficient Of Performance) mesin pending. Penelitian dilakukan di Kampus II Universitas Muhammadiyah Metro, di Laboratorium Teknik Mesin. Metode yang digunakan penelitian ini adalah dengan pembuatan dan pengujian alat mesin pendingin. Pengujian dilakukan pada kondensor menggunakan air dan udara, dengan variasi beban pendingin ruangan 450W, 600W, 750W. Dan debit aliran air di kondensor 0,06 l/s, 0,075 l/s dan 0,09 l/s. Adapun hasil yang didapat dari penelitian ini yaitu COP (Coefficient Of Performance) yang tertinggi yaitu 15,43 terjadi pada pendingin air dengan beban 450 watt pada debit 0,09 1/s. sedangkan dengan pendingin udara COP 6,44 pada beban 450W. Dan temperatur air tertinggi sebesar $38^{\circ} \mathrm{C}$ terjadi pada debit $0,06 \mathrm{l} / \mathrm{s}$ dan pada beban pendingin 750 watt. Ini temperatur airnya cukup tinggi sehingga cukup baik diguinakan untuk air mandi.
\end{abstract}

Kata kunci : Kondensor, Pendingin Air, COP

\section{PENDAHULUAN}

Air Conditioner (AC) adalah suatu proses pendinginkan udara sehingga dapat mencapai temperatur dan kelembaban yang sesuai dengan yang dipersyaratkan terhadap kondisi udara dari suatu ruangan tertentu. Kondensor berfungsi untuk membuang panas yang ada di rerfrigerant kelingkungan dengan menggunakan media udara serta dibantu dengan daya dorong blower, uap refrigerant yang keluar dari kompresor memasuki kondensor uap yang bersuhu tinggi ini sebelum masuk ke evaporator terlebih dahulu di dinginkan di kondensor. Untuk meningkatkan kemampuan kerja alat pendingin COP (Coefficient Of Performance) maka kondensor dapat di modifikasi dengan menggunakan pendingin media air, dan blower tidak digunakan lagi sehingga dapat menghemat daya penggerak blower.

Komponen utama dari penyegar udara adalah kompresor, kondensor, katup ekspansi dan evaporator. Kompresor berfungsi mengalirkan dan menaikan tekanan gas refrigrant yang selanjutnya masuk kedalam kondensor, kondensor ini berfungsi sebagai alat pemidahan panas yang dilepaskan dari uap panas refrigrant kemedia pendingin sehingga uap panas refrigrant akan mengalami pengembunan dan perubahan fase dari keadaan uap menjadi cairan. Pada umumnya kondensor yang dipakai oleh penyegar udara pada instalasi yang kecil digunakan kondensor dengan media pendingin udara. Dari kondensor cairan diekspansikan melalui katup ekspansi selanjutnya dimasukan ke evaporator untuk proses penyerapan panas dari lingkungan sehingga suhu lingkungan menjadi lebih rendah dari sebelumnya.

Kondensor berfungsi untuk membuang panas yang ada di rerfrigerant kelingkungan dengan menggunakan media udara serta dibantu dengan daya dorong blower, uap refrigerant yang keluar dari kompresor memasuki kondensor uap yang bersuhu tinggi ini sebelum masuk ke evaporator terlebih dahulu di dinginkan di kondensor. Untuk meningkatkan kemampuan kerja alat pendingin COP (Coefficient Of Performance) maka kondensor dapat di modifikasi dengan menggunakan media air sehingga pada bagian tersebut kita dapat menghemat daya blower yang tidak di pakai.

Modifikasi tersebut dilakukan untuk menghemat daya listrik dan air merupakan media pendingin penyerap panas yang baik 
dibandingkan dengan udara, sehingga di harapkan panas yang di simpan di refrigrant dapat diserap di kondensor secara maksimal.

Dengan proses pembuangan panas yang baik maka akan terjadi kondensasi (uap panas dari refrigran berubah menjadi cairan atau mengembun) yang baik, dengan proses kondensasi yang baik, maka akan membantuk kerja komponen-komponen yang lainnya khususnya di evaporator akan terjadi proses penyerapan kalor (pengupan cairan refrigran) yang baik dari suatu ruang atau benda sehingga di dapatkan harga COP (Coefficient Of Performance) yang tinggi.

Adapun yang menjadi tujuan dalam penulisan laporan ini antara lain : Untuk mengetahui kemampuan kerja COP (Coefficient Of Performance) setelah di modifikasi dan Untuk mengetahui hubungan perubahan temperatur air yang terjadi pada kondensor terhadap debit yang digunakan.

\section{LANDASAN TEORI}

\section{a. Pengertian AC (Air Conditioner)}

Air Conditioner (AC) Merupakan sebuah alat yang mampu mengkondisikan udara. Dengan kata lain, AC (Air Conditioner) berfungsi sebagai penyejuk udara yang diinginkan ( sejuk atau dingin ) dan nyaman bagi tubuh. AC Lebih Banyak digunakan di wilayah yang beriklim tropis dengan kondisi temperatur udara yang relatif tinggi (panas).

\section{b. Refrigerant}

Refrigerant adalah fluida kerja utama pada suatu siklus refrigerasi yang bertugas menyerap panas pada temperatur dan tekanan rendah dan membuang panas pada temperatur dan tekanan tinggi

Terdapat berbagai jenis refrigerant yang digunakan dalam sistem kompresi uap. Suhu refrigerasi yang dibutuhkan sangat menentukan dalam pemilihan fluida. Refrigerant yang umum digunakan adalah yang termasuk kedalam chlorinated fluoro carbons (CFC, disebut juga Freons): R-11, R-12, R-21, R-22 dan R-502.

\section{c. Kondensor}

1. Kondensor berpendingin air (Water Cooled Condenser)

Kondensor jenis ini digunakan pada system yang berskala besar untuk keperluan komersil di lokasi yang mudah memperoleh air bersih. Kondensor jenis ini menjadi pilihan yang ekonomis bila terdapat suplai air bersih mudah dan murah. Pada umumnya kondensor seperti ini berbentuk tabung yang di dalamnya berisi pipa (tubes) tempat mengalirnya air pendingin.

\section{Kondensor berpendingin udara (Air}

\section{Cooled Condenser)}

Kondensor yang menggunakan udara sebagai cooling mediumnya biasanya digunakan pada sistem berskala rendah dan sedang dengan kapasitas hingga 20 ton refrigerasi. Air Cooled Condenser merupakan peralatan AC (Air Conditioner) standard untuk keperluan rumah tinggal (residental) atau digunakan di suatu lokasi di mana pengadaan air bersih susah diperoleh atau mahal. Untuk melayani kebutuhan kapasitas yang lebih besar biasanya digunakan multiple air colled condenser.

Udara sebagai pendingin kondensor dapat mengalir secara alamiah atau dialiri paksa oleh fan. Kulkas pada umumnya menggunakan kondensor berpendingin udara secara alamiah (konveksi natural) yang umum disebut sebagai kondensor statis.

3. Kondensor berpendingin campuran udara dan air (Evaporative Condenser)

Kondensor jenis ini merupakan kombinasi dari kondensor berpendingin udara dan kondensor berpendingin air. Koil kondensor ini diletakkan berdekatan dengan media pendinginnya yang berupa udara tekan dan air yang disemprotkan melalui suatu lubang nozzle.

\section{d. Siklus Refrigrasi Uap}

Proses-proses yang terjadi pada siklus kompresi uap seperti pada gambar diatas adalah sebagai berikut: 


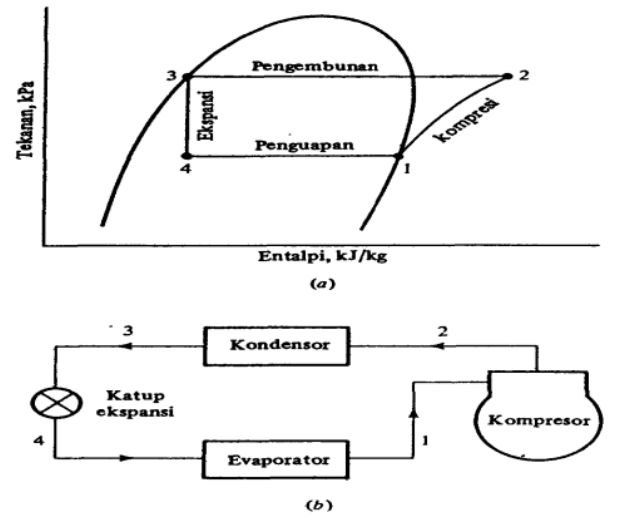

Gambar 1. Siklus Daur kompresi uap

a. Proses Kompresi (1-2)

Proses ini dilakukan oleh kompresor dan berlangsung secara isentropik adiabatik. Karena proses ini berlangsung secara isentropik, maka temperatur ke luar kompresor pun meningkat.

b. Proses Kondensasi (2-3)

Proses ini berlangsung didalam kondensor. Refrigerant yang bertekanan tinggi dan bertemperatur tinggi yang berasal dari kompresor akan membuang kalor sehingga fasanya berubah menjadi cair. Hal ini berarti bahwa di dalam kondensor terjadi pertukaran kalor antara refrigerant dengan media pendingin (air), sehingga panas berpindah dari refrigeran ke air pendingin yang menyebabkan uap refrigerant mengembun menjadi cair.

b. Proses Expansi (3-4)

Proses expansi ini berlangsung secara isoentalpi. Hal ini berarti tidak terjadi perubahan entalpi tetapi terjadi drop tekanan dan penurunan temperatur. Proses penurunan tekanan terjadi pada katup expansi yang berbentuk pipa kapiler atau orifice yang berfungsi untuk mengatur laju aliran refrigerant dan menurunkan tekanan.

c. Proses Evaporasi (4-1)

Proses ini berlangsung secara isobar isothermal (tekanan konstan, temperatur konstan) di dalam evaporator. Panas dari lingkungan akan diserap oleh cairan refrigerant yang bertekanan rendah sehingga refrigerant berubah fasa menjadi uap bertekanan rendah.

\section{e. Perhitungan}

1. Kerja kompresi

Entalpi adalah energi yang dikandung oleh suatu bahan sesuai dengan temperatur dan massa bahan tersebut. Dalam setiap proses refrigerasi yang kita amati adalah perubahan entalpinya. Perubahan entalpi adalah jumlah kalor yang yang diberikan atau diambil dalam tiap satuan massa melalui proses tekanan konstan. Harga entalpi dapat dihitung dengan menggunakan persamaan:

( Supratman Hara,1982)

$$
Q_{w}=h_{2}-h_{1}
$$

Dimana :

$Q_{w}=$ Besarnya panas pada proses kompresor $(\mathrm{kJ} / \mathrm{kg})$

$h_{l}=$ Entalpi refrigerant keluar evaporator dan masuk kompresor $(\mathrm{kJ} / \mathrm{kg})$

$h_{2}=$ Entalpi refrigerant saat keluar kompresor - masuk kondensor $(\mathrm{kJ} / \mathrm{kg})$

2. Besar panas per satuan massa refrigerant yang dilepaskan di kondensor dinyatakan sebagai:

( Supratman Hara,1982)

$$
Q_{c}=h_{2}-h_{3}
$$

Dimana :

$Q_{c}=$ Besarnya panas dilepas di kondensor $(\mathrm{kJ} / \mathrm{kg})$

$h_{3}=$ Entalpi refrigerant saat keluar kondensor $(\mathrm{kJ} / \mathrm{kg})$

3. Besarnya panas yang diserap oleh evaporator

( Supratman Hara,1982)

$$
Q_{e}=h_{l}-h_{4}
$$

Dimana :

$Q_{e}=$ Besarnya panas yang diserap di evaporator $(\mathrm{kJ} / \mathrm{kg})$

$h_{4}=$ Entalpi refrigerant saat masuk evaporator, $(\mathrm{kJ} / \mathrm{kg})$

d. Koefisien Prestasi / Coefficient of Performance (COP)

Koefisien prestasi dari sistem refrigerasi adalah dampak refrigerasi (efek refrigerasi) dibagi dengan kerja kompresi.

$$
\begin{aligned}
\text { COP } & =\frac{\text { dampakrefrigerasi }}{\text { kerja kompresi }} \\
& =\frac{h_{1}-h_{4}}{h_{2}-h_{1}} \\
& (\text { Supratman Hara,1982) }
\end{aligned}
$$




\section{METODE PENELITIAN}

Penelitian ini dilakukan di Laboratorium teknik mesin Universitas Muhammadiyah Metro. Pengujian menggunakan AC split, dengan pembuatan prangkat alat uji dimana kondensor dimodifikasi dengan mengganti blower dengan bak air tempat kondensor.

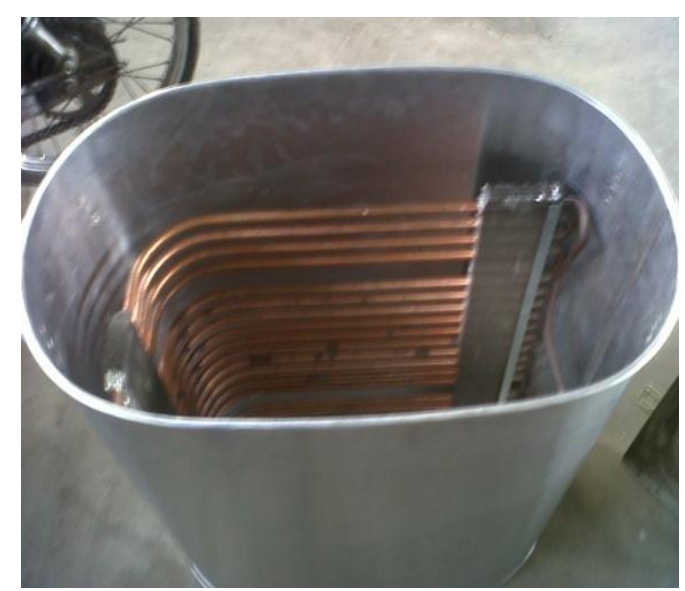

Gambar 2. Kondensor air

Kemudian alat tersebut uji dengan mengambil data temperatur pada air dan kondensor serta pada bagian kompresor, pipa kapiler dan evaporator. dengan variasi beban pendingin ruangan $450 \mathrm{~W}$, 600W, $750 \mathrm{~W}$.

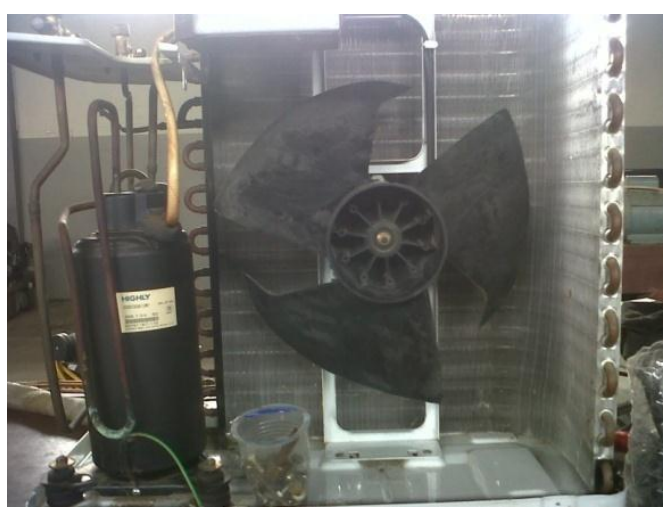

Gambar 3. Kondensor dan kompresor

Air pendingin kondensor dibuat mengalir dengan debit aliran air bervariasi $0,06 \mathrm{l} / \mathrm{s}, 0,075 \mathrm{l} / \mathrm{s}$ dan $0,09 \mathrm{l} / \mathrm{s}$. Tujuannya untuk mendapatkan pendinginan yang lebih baik dan air panas tersebut dapat digunakan untuk keperluan lain seperti air mandi.

\section{HASIL DAN PEMBAHASAN}

Hubungan Perbandingan Pengaruh COP Terhadap Variabel Debit Pendinginan Konstan Serta Variabel Beban dan Pendingin Dengan Blower

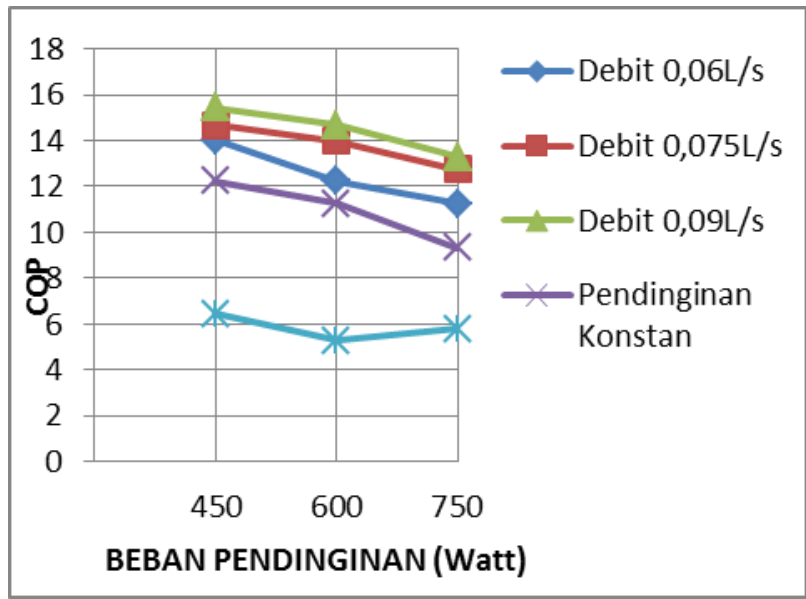

Gambar 4. Grafik hasil COP terhadap variabel beban pendinginan

Dari hasil pengujian yang didapat seperti pada gambar 4.1. terlihat bahwa semakin kecil beban pendinginan maka COP yang dihasilkan semakin besar dan sebaliknya semakin besar beban pendinginan maka COP-nya semakin kecil. Hal ini dikarena semaikin besar beban maka panas yang diserap evaporator semakin besar dan ini akan manurunkan kemempuan kerja alat pendingin. Juga sebaliknya.

Pada gambar tersebut juga terlihat bahwa COP yang tertinggi terjadi pada beban yang lebih kecil yaitu 450 watt dan pada debit aliran air yang mengaliri condensor yaitu debit yang besdar 0,09 liter/detik (1/s). Dan sebaliknya pada debit yang kecil menghasilkan COP yang kecil pula. Hal ini dikarenakan debit yang besar akan dapat mendinginkan air condensor lebih baik dibanding debit yang kecil. Dimana panas yang ada akan dialirkan dan dibawa keluar dan digantikan atau diisi lagi oleh air yang baru sehingga kondensor akan senantiasa lebih dingin. 
Hubungan temperatur air didalam kondensor terhadap pengaruh debit dan beban yang digunakan

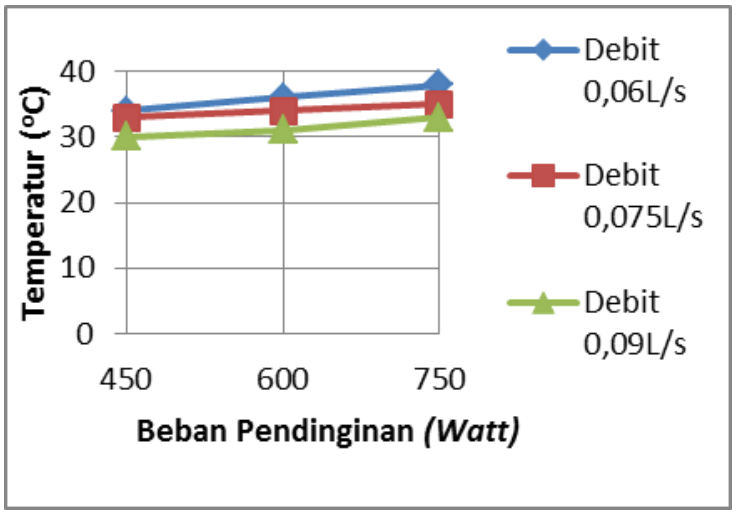

Gambar 5. Grafik hubungan tempratur air kondensor terhadap beban pendinginan.

Pada gambar 5 grafik hubungan tempratur air kondensor terhadap beban pendinginan terlihat bahwa semaikin besar beban pendinginan maka temperatur yang terjadi pada temperatur air di kondensor semakin besar pula, namun debit aliran airnya semakin lebih kecil. Dan sebaliknya semakin lebih kecil beban pendinginan, semakin kecil juga temperatur yang terjadi pada air condensor, namun debit yang terjadi semakin lebih besar. Hal ini terjadi karena semikin lebih besar debit aliran air maka penyerapan panas pada air semikin kecil karena panas yang telah terserap air segera dibawa ke luar dan langsung digantikan dengan air yang baru sehingga panas yang terserap air dikondensor pada debit yang besar tidak lebih besar dari panas yang diserap pada debit yang kecil.

Untuk temperatur air mandi yang ideal disarankan $32-35^{\circ} \mathrm{C}$, bahwa dengan debit $0,06 \mathrm{~L} / \mathrm{s}$ dengan pembeban $450 \mathrm{~W}, 600 \mathrm{~W}$ dan 750W temperatur air didalam kondensor didapatkan data untuk beban $450 \mathrm{~W}$ temperatur air $34^{\circ} \mathrm{C}$ sedangkan dengan beban $600 \mathrm{~W}$ temperatur air $36^{\circ} \mathrm{C}$ dan beban $750 \mathrm{~W}$ temperatur air mencapai $38^{\circ} \mathrm{C}$ bisa dimanfaatkan sebagai mandi air hangat dan untuk COPnya cukup tinggi, sedangkan dengan debit $0,075 \mathrm{~L} / \mathrm{s}$ dengan pembebanan ruangan $450 \mathrm{~W}$, $600 \mathrm{~W}, 750 \mathrm{~W}$, temperatur air didalam kondensor didapatkan data $33^{0} \mathrm{C}$ dengan beban 450W, dan pembebanan $600 \mathrm{~W}$ temperatur air $34^{\circ} \mathrm{C}$ untuk beban $750 \mathrm{~W}$ didapatkan temperatur air $35^{\circ} \mathrm{C}$ jadi temperatur air didalam kondensor masih ideal untuk mandi air hangat dan COPnya masih bagus, sedangkan dengan debit 0,09L/s dengan pembebanan 450W didapatkan data temperatur air $30^{\circ} \mathrm{C}$ dan beban $600 \mathrm{~W}$ temperatur air $31^{\circ} \mathrm{C}$, beban $750 \mathrm{~W}$ temperatur air $33^{\circ} \mathrm{C}$, jadi dengan debit 0,09L/s temperatur air tidak ideal untuk mandi air hangat karna masih dibawah $32^{\circ} \mathrm{C}$ dan untuk hasil COPnya baik.

\section{KESIMPULAN}

Berdasarkan dari hasil penelitian yang telah dijelaskan pada bagian pembahasan, dapat disimpulkan bahwa :

1. Untuk nilai COP tertinggi pendinginan dengan blower sebelum dimodifikasi 6,44 sedangkan dengan pendinginan media air tertinggi sesudah dimodifikasi 15,43 jadi pendinginan media air lebih baik dibandingkan pendingin udara.

2. Semakin kecil debit semakin besar temperatur airnya dan sebaliknya semakin besar debit semakin kecil temperatur airnya dan pada debit $0,06 \mathrm{~L} / \mathrm{s}$ temperatur air mencapai $38^{\circ} \mathrm{C}$ dan debit $0,075 \mathrm{~L} / \mathrm{s}$ temperatur air mencapai $35^{\circ} \mathrm{C}$ dan debit $0,09 \mathrm{~L} / \mathrm{s}$ temperatur air mencapai $33^{\circ} \mathrm{C}$.

\section{Daftar Pustaka}

1. Made Rasta, pemanfaatan Energi Panas Terbuang Pada Kondensor AC Sentral Jenis Ware Chiller untuk Pemanas Air Hemat Energi, Politeknik Negri Bali, 2009. 
2. Patamah Siti, Analisis Pengaruh Elevasi Aliran Air Pendingin Kondensor Terhadap Laju Perpindahan Kalor Dan Efisiensi Kerja Mesin, Universitas Islam Negri Malang.2008

3. Purwanto Edi, Pengaruh Jenis Refrigrant dan Beban Pendingin Terhadap Kemampuan Kerja Mesin Pendingin, Universitas Muhammadiyah Metro. 2014

4. Supratman H. Refrigerasi Dan Pengkondisian Udara, Edisi Kedua, Erlangga, Jakarta, 1982.

5. Wahyu T, sumaryanto D. Pedoman Praktis Merawat Ac Mobil. Erlangga. 2011.

6. Wiranto Arismunandar, H.Saito. Penyegaran Udara. Edisi keempat, PT. Pradnya Paramita, Jakarta. 1991

7. Wirawan IKG, Ngurah Putra Wibawa, Analisa Penggunaan Water Kondensor Pada Mesin Pengodisian Udara Paket (AC Widow), Universitas Udayana, Kampus Bukit Jimbaran, 2007 